\title{
Living and growing valve replacements for children: So near yet so far
}

\author{
Farhan Zafar, MD, and David L. S. Morales, MD
}

\author{
From The Heart Institute, Cincinnati Children's Hospital, Cincinnati, Ohio. \\ Disclosures: Morales is a consultant for Berlin Heart, HeartWare, and SynCardia. Zafar has nothing to disclose \\ with regard to commercial support. \\ Received for publication May 24, 2017; accepted for publication May 24, 2017; available ahead of print June 27, \\ 2017. \\ Address for reprints: David L. S. Morales, MD, Cincinnati Children's Hospital Medical Center, Department of \\ Cardiovascular Surgery, 3333 Burnet Ave, Cincinnati, OH 45229 (E-mail: david.morales@cchmc.org). \\ J Thorac Cardiovasc Surg 2017;154:e63-4 \\ $0022-5223 / \$ 36.00$ \\ Copyright (c) 2017 by The American Association for Thoracic Surgery \\ http://dx.doi.org/10.1016/j.jtcvs.2017.05.081
}

Valve replacements in children are limited by their longevity, need for anticoagulation, and lack of growth, which demand a lifelong burden of valve replacements/interventions with significant interim and procedural morbidity. The "ideal valve" will take the form of native tissue with normal growth and function, and thus not require anticoagulation. Recently, tubular valves made from porcine-derived, extracellular matrix have encouragingly shown these properties in animal studies. ${ }^{1,2}$ Tubular valves in the tricuspid position, working like a Heimlich valve, created from a variety of materials have been well documented in the literature to be functionally sound. Reassured by these and similar findings, surgeons have successfully used CorMatrix valves (Roswell, Ga) in more than 200 atrioventricular valve positions both in adult and pediatric patients. $^{3-5}$ In this issue of the Journal, Murala and colleagues ${ }^{5}$ have reported the use of such valves in the mitral and tricuspid position. Although just 2 infants were included, the 11- and 9-month follow-up outcomes with signs of "growth" and only aspirin for anticoagulation are reassuring. Particularly reassuring is the use in the $12-\mathrm{mm}$ mitral annulus of a $3-\mathrm{kg}$ child, in whom use of the smallest mechanical valve (St Jude Medical Hemodynamic Plus $15 \mathrm{~mm}$ [St Paul, Minn]) would have been a challenge.

CorMatrix tricuspid valves currently are being studied under a phase 1 clinical trial in both pediatric and adult patients. A similar clinical trial for evaluation of this valve as a mitral valve replacement in neonates and small infants is currently being considered.

Although CorMatrix valve construct has shown early success, as Murala and colleagues ${ }^{5}$ discussed, the CorMatrix has not been effective in all cardiovascular applications. What we know about the resorptive potential, underlying mechanisms of cell proliferation, nonimmunogenicity, and remodeling of this matrix is limited. How the growth factors and cytokines from these scaffolds populate and attract phenotypically similar cells is actively being studied. As

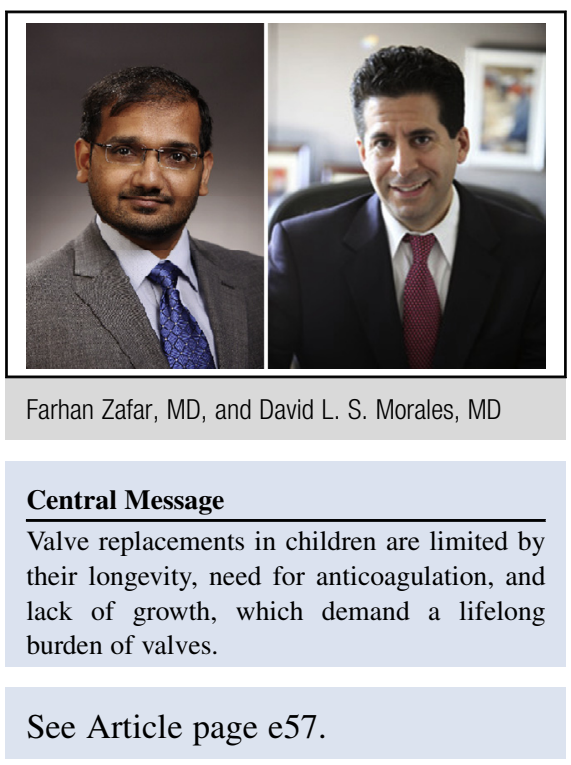

we know from embryogenesis, there is a significant interplay between the dynamic cardiac environment and the atrioventricular valve maturation from a tube to a fully developed valve with chordae. ${ }^{6}$ There is a significant contribution of tactile signals (stress/strain) to the way this matrix responds, and thus different implant locations and even techniques have variable results. Another concern, which currently is shared by almost all tissue-engineering products, is the inconsistency in manufacturing processes of cell or non-cell-based constructs, perhaps contributing to these rare but documented inconsistent tissue responses. Most of these tissue-engineered products in general are a result of innovation at academic centers with formation of small startups around them, which may not be entirely equipped for scaled-up production. Recognizing this issue, the US Government funded a large initiative in December 2016 to organize collaboration and bring all stakeholders together in a new consortium under the Manufacturing USA network, to provide systemized testing/manufacturing for tissue-engineered products. Skepticism is somewhat justified; however, what we know so far is that the CorMatrix can remodel at times. This should drive us toward learning how it works in some places and why it fails in others, because achieving a tissue-engineered valve, "the ideal valve" will change the lives of countless patients.

\section{References}

1. Zafar F, Hinton RB, Moore RA, Baker RS, Bryant R III, Narmoneva DA, et al Physiological growth remodeling potential and preserved function of a novel 
bioprosthetic valve: tubular bioprosthesis made of small intestinal submucosaderived extracellular matrix. J Am Coll Cardiol. 2015;66:877-88.

2. Fallon AM, Goodchild TT, Cox JL, Matheny RG. In vivo remodeling potential of a novel bioprosthetic tricuspid valve in an ovine model. J Thorac Cardiovasc Surg. 2014; 148:333-40.

3. Bibevski S, Scholl FG. Feasibility and early effectiveness of a custom, hand-made systemic atrioventricular valve using porcine extracellular matrix (CorMatrix) in a 4-month-old infant. Ann Thorac Surg. 2015;99:710-2.
4. Gerdish MW, Boyd WD, Harlan JL, Richardson JB, Flack JE, Palafox BA, et al. Early experience treating tricuspid valve endocarditis with a novel extracellular matrix cylinder reconstruction. J Thorac Cardiovasc Surg. 2014;148:3042-8.

5. Murala JSK, Sassalos P, Owens ST, Ohye RG. Porcine small intestine submucosa cylinder valve for mitral and tricuspid valve replacement. J Thorac Cardiovasc Surg. 2017; 154:e57-9.

6. Bartman T, Hove J. Mechanics and function in heart morphogenesis. Dev Dyn Off Publ Am Assoc Anal. 2005;233:373-81. 